\title{
THE WORKSHOP IN CREATING PERSONAL IN THE FIELD OF PFYSICAL CULTURE AND SPORTS
}

\author{
Galina Yamaletdinova, Vera Makeeva, Evgenie Letunov, \\ Valentina Pushkina, Irina Gernet
}

\begin{abstract}
The program of discipline "Physical culture and sports", is developed on the basis of features of federal state educational standard 3 and includes universal competence and indicators of its success, aiming at self-organization and selfdevelopment (including maintaining health). The research purpose - to create information and the diagnostic system of self-government for personal development and psychophysical readiness of students, athletes, disabled people. Methods. Synthesis of experience, pedagogical observation, information-computer technologies, experiment. In the research also information approaches in personal development of respondents leaned on system, activity. Results. A set of changes in indicators of the self-assessment accepted on a 5-mark scale had positive dynamics: the ability to self-government improved on 1.3 points; physical health on 2 points, physical shape on 1, 6 points, vocational training - on 1.9 points, technical training - on 1 point. Occupations on the basis of inclusion of an information and diagnostic system promotes formation at students of ability to operate the cognitive activity, to treat health as to value, promoted active manifestation of self-government. Conclusion. The developed system creates conditions for increase in motivation for systematic physical activity and sporting events.
\end{abstract}

Key words: health, students, information technologies, self-government.

\section{INTRODUCTION}

While creating the program of the discipline "Physical culture and sports," it is necessary to take into account the peculiarities of the new Federal State Education Standard: universal competence and indicators of its success intended to self-management and self-development (including health protection). The graduate of a higher education institution should be competent in designing the strategy of individual fitness and sports programs.

The crucial task of modern higher education is the development of effective methods to stimulate the learning and cognitive activity of students. Such education a priori should unlock the spiritual and physical strength of man. In fact, this means maximizing the human potential.

At the same time fitness and sports activity, its values and self-management ability is the most important factor of adaptation, achievement of professional personhood and optimal combination of social and biological activities in it (Yamaletdinova, 2013). The summary of results of scientific research shows that there is a trend towards introduction of information technologies in the field of modern physical culture and sports (Weinberg, Gould, 2011).

Nowadays information technology is being applied both as a design process and as a design output.
Different types of application software oriented to educational attainment, motor skills, development of physical qualities, mastering of elements of technical and tactical training are used (Yamaletdinova, 2015). But not always diagnostics of psychophysiological and physical states is considered at grade levels that leads to expenses of educational process, and excludes multidimensional and integrative role of physical culture in holistic methodology which is directed to individual improvement (Makeeva et al., 2017). It is incumbent upon the designers of methodological tools to find modern methods of training and individual improvement. Using the information technologies resources allows to automate the process of self-diagnosis, to form an active-transformative attitude to the received information, to develop personal projects of various categories for students studying on the chosen sport or system of physical exercises and to correlate the psychophysical state depending on life and professional tasks (Polyevsky et al., 2013).

The aim of the study is to develop and implement the information and diagnostic system for assessing the psychophysical conditions of students in the creation of personal projects of self-government in physical culture and sports, which contribute to the development of the respondents' personality. 


\section{METHODS}

Organization of the study. The study involved fulltime students from six faculties of the Liberal Arts University, studying at seventeen training programs. More than 4000 people in total.

At the first stage of the study we analyzed the psychology and pedagogical literature, conducted pedagogical observation in accordance with the idea of integral characteristics of man as a person and a subject (Zaks, 2016) and summarized practical experience. We used the approaches of general scientific level of methodology: systems approach (Blauberg et al., 1978), personal-activity approach, information approach (O'Connor, McDermott, 2018) and individually differentiated approach.

Based on the analysis of the obtained data, we designed the program of diagnostic procedures. The program allows to select the most significant indicators, that are essential in the design of personal programs of readiness for professional and sports activity in the form of five modules (Figure 1).

The program includes a specific group of methods and allows students to select and modify self-diagnostics algorithms according to the main task under consideration. For the implementation of the program we develop a methodological set of tools including the health certificate, the user's manual and instructions for the creation of personal project. A student enters his or her indicators and results into the health certificate and carries out comparative and collation analysis. Each methods requires the measurement of certain indicators, which are automatically processed according to the specified algorithms with the help of the developed information and diagnostic system.



Figure 1. The main window of the program

Student data is stored in the program, so that he or as the peculiarities of their future professional acshe does not have to enter it every next time. You can manually or automatically delete (correct) the entered indicators, thereby checking the effectiveness of the step-by-step management transition to the self-management of the respondent's cognitive activity. The program can be personalized for each user. It is possible to select a color theme, to change the font size, to use a timer when passing tests.

At the second stage we carried out an ascertaining experiment. During the experiment comprehensive self-diagnosis of the psychophysical states of respondents was carried out in accordance with the peculiarities of the discipline "Physical culture". It also took into account the psychophysical capabilities of various categories of respondents (schoolchildren, students, athletes, disabled persons, people with physical disabilities, etc.), as well tivities, needs and interests. On the basis of individual preferences three experienced groups of first-year students have been created: sports (S), professional $(\mathrm{P})$, recreational $(\mathrm{R})$ and control group (C), engaged in the traditional version of classes.

At the third stage of the study we carried out an educational experiment in terms of which personal self-government and self-development projects in the discipline "Physical culture" were designed. These projects are individual training program on the example of a specific sport or a system of health-improving physical exercises. The project was developed by students at methodological classes on the basis of computer programs in training sessions on elective disciplines "Fitness", "Hand-tohand fighting kudo", "Athletic gymnastics", "Health 
related training", "Basketball", etc.

At the fourth stage of the research we analyzed the significance of outcome of the experiment on the formation and development of psychological and pedagogical foundations of self-government. We also proved the effectiveness of the information and diagnostic system for the creation of personal projects, provided statistical processing of data was and determined the efficiency of projects development.

\section{RESULTS AND DISCUSSION}

At the first stage of the study, based on the diagnostic procedures carried out, the most important indicators were selected, which are essential for personal programs of readiness for professional, sports and fitness activities, and the program including the methodological tool for evaluation of psychophysical states of respondents in the form of five modules was developed.

The first module allows to detect the state of physical health and characterizes the factors affecting its change.

The second module includes methods of assessment of physical state level on the basis of non-loading tests, as well as tests with dosed load. Taking into account the detected level of physical profile by the specific respondent the volume and intensity of physical activity on the basis of the chosen sport is determined.
The third module is presented by research methods of functional state of respiratory and cardiovascular systems of organism in the form of indices and indicators.

The fourth module is aimed at determining the level of formation of cognitive processes of the person: stability, volume, distribution and switching of attention; visual, figurative and operative memory; evaluation of thinking logic.

The fifth module reflects the development of abilities for self-knowledge and self-determination, self-realization and self-education, tendencies to communication and organization, skills of the respondent to live a healthy lifestyle, etc.

At the second stage of the study, on the basis of the results of the first three modules, procedures were carried out to test the indicators of health and physical condition at the ascertaining stage of the experiment. The results are presented in Table 1. As the analysis of the test results showed, the function of the leading body systems of the respondents of the test and control group has in most cases insufficient level of formation of indicators that reflect health and physical condition. At the same time there is a significant non-uniformity of results within groups according to the coefficient of variation.

Table 1. Assessment of the health and physical condition of female students at the ascertaining stage of the experiment

\begin{tabular}{|l|l|l|l|l|l|l|l|}
\hline \multirow{2}{*}{ Groups } & \multicolumn{7}{|c|}{ Indicators } \\
\cline { 2 - 8 } & $\begin{array}{l}\text { Biological } \\
\text { age, years }\end{array}$ & $\begin{array}{c}\text { Physical } \\
\text { health, } \\
\text { point }\end{array}$ & $\begin{array}{c}\text { Cardiac } \\
\text { risk, } \\
\text { relative } \\
\text { units }\end{array}$ & $\begin{array}{c}\text { Adaptive } \\
\text { potential, } \\
\text { point }\end{array}$ & $\begin{array}{c}\text { Non-load- } \\
\text { ing test, } \\
\text { point }\end{array}$ & $\begin{array}{c}\text { Ruffier's } \\
\text { test, point }\end{array}$ & $\begin{array}{c}\text { Cardiovascular } \\
\text { endurance ratio, } \\
\text { point }\end{array}$ \\
\hline \multirow{2}{*}{$\mathrm{S}^{*}$} & $24,8 \pm 0,97$ & $2,71 \pm 0,95$ & $9,88 \pm 1,30$ & $4,63 \pm 0,12$ & $3,56 \pm 0,21$ & $3.00 \pm 0,20$ & $16,40 \pm 0,32$ \\
\hline \multirow{2}{*}{$\mathrm{P}^{*}$} & 17 & 90 & 56 & 11 & 25 & 29 & 6 \\
\hline \multirow{2}{*}{$\mathrm{R}^{*}$} & $24,60 \pm 1,17$ & $1,70 \pm 0,22$ & $14,85 \pm 0,77$ & $4,38 \pm 0,11$ & $3,33 \pm 0,16$ & $2,84 \pm 0,17$ & $21,35 \pm 2,16$ \\
\hline \multirow{2}{*}{$\mathrm{C}^{*}$} & $27,41 \pm 1,36$ & $2,19 \pm 0,89$ & $10,66 \pm 1,14$ & $3,00 \pm 0,02$ & $3,36 \pm 0,19$ & $2,55 \pm 0,32$ & $24,00 \pm 1,27$ \\
\cline { 2 - 8 } & 17 & 142 & 37 & 9 & 20 & 44 & 23 \\
\cline { 2 - 8 } & $30,09 \pm 1,48$ & $2,75 \pm 0,26$ & $13,27 \pm 1,37$ & $4,50 \pm 0,15$ & $3,00 \pm 0,25$ & $2,67 \pm 0,34$ & $23,71 \pm 3,91$ \\
\hline
\end{tabular}

Author's note: * top line $-M \pm m$; bottom line $-V, \%$

Particularly significant differences are observed in the group "Sport" the coefficient of variation charhealth indicators from 32 to $90 \%$; risk of heart dis- acterizes changes in normal variant. In other groups ease from 36 to $56 \%$; load test (Ruffier's test) - from it reflects significant fluctuation ranging from 23 up 29 to $44 \%$. As for the indicators of the ratio of en- to $68 \%$. There is a clear trend of low level of physical durance of the cardiovascular system, then only in condition while performing a non-loading test and 
a test using standard physical activity. Heart performance in both tests indicates a low level of training: average in non-loading and below average in load test: from 2.99 to 2.67 points. This confirms the necessity to determine effective means, methods, forms of organization of training classes.

We assessed the level of individual development including in particular the level of physical culture (PC) maturity on the basis of the fourth module data (Table 2).

The analysis of the results revealed a poorly interested (low) level of physical culture maturity among female students of experienced groups $\mathrm{P}, \mathrm{R}$ and control group and a higher active level in the group "Sport." The obtained data show that the level of theoretical knowledge of the majority of students in the subject is insufficient. Indicators of cognitive processes (stability, volume, distribution and switching of attention; eidetic, image and operative memory; evaluation of thinking logic) at the summative stage of the experiment do not differ significantly from each other in all test and control groups $(\mathrm{P}>0.05)$ and have high values. At the same time the function of attention volume is most developed while shortterm eidetic memory is less developed. This also confirms a low coefficient of variation of up to $3 \%$.

Table 2. Self-assessment of physical culture maturity at the initial stage of the experiment (points)

\begin{tabular}{|c|c|c|c|c|c|}
\hline \multirow[b]{2}{*}{ Groups } & \multirow[b]{2}{*}{$\begin{array}{c}\text { Level of } \\
\text { occurrence, } \\
\text { point }\end{array}$} & \multicolumn{4}{|c|}{ Its elements, point } \\
\hline & & $\begin{array}{c}\text { Focus } \\
\text { on values } \\
\text { of PC }\end{array}$ & $\begin{array}{c}\text { Knowledge } \\
\text { in the Field } \\
\text { of PC }\end{array}$ & $\begin{array}{l}\text { Conscious relevant } \\
\text { emotional-volition- } \\
\text { al activity in the } \\
\text { Field of PC }\end{array}$ & $\begin{array}{c}\text { Competent readiness } \\
\text { for systematic } \\
\text { productive activities in } \\
\text { the field of PC }\end{array}$ \\
\hline \multirow[t]{2}{*}{$S^{*}$} & $\begin{array}{c}54,29 \pm 0,79 \\
\text { average }\end{array}$ & $\begin{array}{c}19,58 \pm 0,80 \\
\text { average }\end{array}$ & $\begin{array}{c}11,67 \pm 0,18 \\
\text { high }\end{array}$ & $\begin{array}{c}12,00 \pm 0,84 \\
\text { average }\end{array}$ & $\begin{array}{c}11,04 \pm 0,32 \\
\text { high }\end{array}$ \\
\hline & 6 & 10 & 7 & 9 & 7 \\
\hline \multirow[t]{2}{*}{$\mathbf{P}^{*}$} & $\begin{array}{c}40,13 \pm 1,04 \\
\text { low }\end{array}$ & $\begin{array}{c}15,13 \pm 0,45 \\
\text { low }\end{array}$ & $\begin{array}{c}7,20 \pm 0,24 \\
\text { low }\end{array}$ & $\begin{array}{c}10,27 \pm 0,22 \\
\text { low }\end{array}$ & $\begin{array}{c}7,53 \pm 0,20 \\
\text { low }\end{array}$ \\
\hline & 16 & 19 & 21 & 14 & 17 \\
\hline \multirow[t]{2}{*}{$\mathbf{R}^{*}$} & $\begin{array}{c}44,21 \pm 1,37 \\
\text { low }\end{array}$ & $\begin{array}{l}16,78 \pm 0,55 \\
\text { low }\end{array}$ & $\begin{array}{c}8,00 \pm 0,55 \\
\text { low }\end{array}$ & $\begin{array}{c}11,10 \pm 0,43 \\
\text { low }\end{array}$ & $\begin{array}{c}8,33 \pm 0,37 \\
\text { low }\end{array}$ \\
\hline & 13 & 14 & 29 & 17 & 19 \\
\hline \multirow[t]{2}{*}{$\mathrm{C}^{*}$} & $\begin{array}{c}46,00 \pm 1,70 \\
\text { low }\end{array}$ & $\begin{array}{c}17,00 \pm 0,80 \\
\text { low }\end{array}$ & $\begin{array}{c}9,00 \pm 0,49 \\
\text { low }\end{array}$ & $\begin{array}{c}11,00 \pm 0,72 \\
\text { low }\end{array}$ & $\begin{array}{c}9,00 \pm 0,45 \\
\text { low }\end{array}$ \\
\hline & 14 & 19 & 21 & 25 & 24 \\
\hline
\end{tabular}

Author's note: ${ }^{\star}$ top line $-M \pm m$; bottom line $-V, \%$

The results of self-evaluation of all types of self-government abilities revealed their low level in female students of all groups. Analysis of the results revealed that in groups $\mathrm{S}$ and $\mathrm{C}$ abilities for self-government are just higher than average level, at the same time the abilities for self-knowledge are most developed. However, the low coefficient of variation in the group "Sport" (6\%) indicates the most developed skills for cognitive activity to create personal projects of self-improvement and its relationship with the future profession. In groups $\mathrm{P}$ and $\mathrm{R}$, the ability to self-government is shown at the middle level, where the type of personality abilities manifests itself as self-galling and amateur (Table 3).

During the formative stage of the experiment, respondents of experienced groups created personal projects within the framework of various sports (running, swimming, cycling, etc.) and systems of health exercises, taking into account their individual capabilities and preferences. The effectiveness of the developed projects can be proved by the combination of positive changes in the indicators (in points): physical health from 2.7 to 4.7 ; physical shape - from 1.8 to 3.4 ; readiness for professional activity - from 2.6 to 4.5 ; technical maturity - from 3.8 to 4.9 ; ability to self-management from 2.8 to 4.3 . The detected dynamics of indicators confirms the effectiveness of the developed program, built on the basis of the information and diagnostic system. This proves that the inclusion of information and diagnostic system into methodological classes of experienced groups changes attitude to health as value, stimulates motivation to systematic sports activities, promotes the ability to manage the cognitive activity. 
Table 3. Indicators of maturity of ability types to self-government of female students at the initial stage of the experiment (points)

\begin{tabular}{|c|c|c|c|c|c|c|c|c|c|c|}
\hline \multirow[b]{2}{*}{ Groups } & \multirow[b]{2}{*}{$\begin{array}{l}\text { Ability } \\
\text { types to } \\
\text { self-ma- } \\
\text { nagement }\end{array}$} & \multicolumn{9}{|c|}{ Ability types to: } \\
\hline & & $\begin{array}{l}\text { Self- } \\
\text { cogni- } \\
\text { tion }\end{array}$ & $\begin{array}{c}\text { Self- } \\
\text { identity }\end{array}$ & $\begin{array}{c}\text { Self- } \\
\text { orga- } \\
\text { ni- } \\
\text { zation }\end{array}$ & $\begin{array}{l}\text { self-rea- } \\
\text { lization }\end{array}$ & $\begin{array}{c}\text { self-ac- } \\
\text { tivity }\end{array}$ & $\begin{array}{c}\text { self-su- } \\
\text { per- } \\
\text { vision }\end{array}$ & $\begin{array}{c}\text { self-as- } \\
\text { sessment }\end{array}$ & $\begin{array}{l}\text { auto-sug } \\
\text { gestion }\end{array}$ & $\begin{array}{l}\text { self-deve- } \\
\text { lopment }\end{array}$ \\
\hline \multirow[t]{2}{*}{$S^{*}$} & $\begin{array}{c}81,86 \pm \\
1,24 \\
\end{array}$ & $\begin{array}{c}10,00 \pm \\
0,46\end{array}$ & $\begin{array}{c}10,33 \pm \\
0,53 \\
\end{array}$ & $\begin{array}{c}9,67 \pm \\
0,56 \\
\end{array}$ & $\begin{array}{c}9,33 \pm \\
0,45\end{array}$ & $\begin{array}{c}7,33 \pm \\
0,52 \\
\end{array}$ & $\begin{array}{c}7,67 \pm \\
0,40 \\
\end{array}$ & $\begin{array}{c}9,00 \pm \\
0,44\end{array}$ & $\begin{array}{c}9,33 \pm \\
0,57\end{array}$ & $\begin{array}{c}9,20 \pm \\
0,76\end{array}$ \\
\hline & 6 & 16 & 18 & 20 & 17 & 25 & 18 & 17 & 21 & 5 \\
\hline \multirow[t]{2}{*}{$\mathbf{P}^{\star}$} & $\begin{array}{c}72,97 \pm \\
1,30\end{array}$ & $\begin{array}{c}7,44 \pm \\
0,22\end{array}$ & $\begin{array}{c}8,24 \pm \\
0,25\end{array}$ & $\begin{array}{c}9,06 \pm \\
0,24\end{array}$ & $\begin{array}{c}8,88 \pm \\
0,27\end{array}$ & $\begin{array}{c}8,82 \pm \\
0,29\end{array}$ & $8,35 \pm 0,30$ & $\begin{array}{c}7,59 \pm \\
0,31\end{array}$ & $\begin{array}{c}6,94 \pm \\
0,30\end{array}$ & $\begin{array}{c}7,65 \pm \\
0,27\end{array}$ \\
\hline & 75 & 21 & 19 & 18 & 19 & 21 & 23 & 25 & 26 & 25 \\
\hline \multirow[t]{2}{*}{$\mathbf{R}^{*}$} & $76,62 \pm 1,54$ & $\begin{array}{c}8,33 \pm \\
0,39 \\
\end{array}$ & $\begin{array}{c}8,00 \pm \\
0,31\end{array}$ & $\begin{array}{c}8,40 \pm \\
0,49 \\
\end{array}$ & $\begin{array}{c}8,45 \pm \\
0,39\end{array}$ & $\begin{array}{c}9,67 \pm \\
0,47 \\
\end{array}$ & $8,44 \pm 0,24$ & $\begin{array}{c}8,33 \pm \\
0,31\end{array}$ & $\begin{array}{c}7,56 \pm \\
0,31\end{array}$ & $\begin{array}{c}9,44 \pm \\
0,24\end{array}$ \\
\hline & 62 & 20 & 17 & 25 & 19 & 21 & 12 & 16 & 18 & 11 \\
\hline \multirow[t]{2}{*}{$C^{\star}$} & $\begin{array}{c}79,73 \pm \\
1,90\end{array}$ & $\begin{array}{c}9,91 \pm \\
0,64\end{array}$ & $\begin{array}{c}8,27 \pm \\
0,75\end{array}$ & $\begin{array}{c}9,00 \pm \\
0,77\end{array}$ & $\begin{array}{c}9,18 \pm \\
0,65\end{array}$ & $\begin{array}{c}9,64 \pm \\
0,74\end{array}$ & $8,55 \pm 0,56$ & $\begin{array}{c}9,18 \pm \\
0,63\end{array}$ & $\begin{array}{c}7,91 \pm \\
0,96\end{array}$ & $8,09 \pm 0,81$ \\
\hline & 56 & 17 & 22 & 21 & 17 & 19 & 16 & 17 & 26 & 21 \\
\hline
\end{tabular}

Author's note: ${ }^{*}$ top line $-M \pm m$; bottom line $-V, \%$

\section{CONCLUSION}

The results of the study let us find out the level of physical health, efficiency, integrity of personality qualities and knowledge processes for the development and correction of individual training programs, which contribute to intensification of self-processes in the field of physical culture, sports and future professional activities.

\section{REFERENCES}

Blauberg, I.V., Sadovsky, V.N. and Yudin, E.G. (1978). Philosophical Principle of Systemicity and the Systems Approach, in Philosophy questions, 1978, No. 8, pp. 39-52. Makeeva, V. S., Barkalov, S. N., Pushkina, V. N. and Olyashev, N. V. (2017). Managing psychophysical readiness in student athletes at law institutes of higher education, in Russian Psychological Journal, 2017, V. 14, no. 3, pp. 210-228.

O'Connor, J. and McDermott, I. (2018). The Art of Systems Thinking: Essential Skills for Creativity and Problem Solving, Alpina Publisher, Moscow, pp.139-145.

Polyevsky, S. A., Raevsky, R. T. and Yamaletdinova, G.A. (2013). Professional and military application of extreme sports activity, Liberal Arts University, Ekaterinburg, 213p.
Weinberg, R. and Gould, D. (2011). Foundations of sport and exercise psychology, Human Kinetics. Champaign, IL.

Yamaletdinova, G.A. (2013). System of self-government of educational and cognitive activities of students in the field of physical culture, Liberal Arts University, Ekaterinburg, 278p.

Yamaletdinova, G.A. (2015). Information technologies in ensuring the self-management of educational and cognitive activities of students on physical culture, Liberal Arts University, Ekaterinburg, 117p.

Zaks, L. A. (2016). On Axiology of the Internet, in Izvestia of Ural Federal University Journal, Series 3, Social and Political Sciences, 2016, No. 3 (155), Ural Federal University, Ekaterinburg, pp.11-24

Corresponding author:

Galina Yamaletdinova Ed.D.

Associate Professor, Chairholder of health improvement and professionally applied physical training,

Liberal Arts University, 620049, 19 Studencheskaya street, Ekaterinburg, Russia; Professor of Department of the theory of physical culture, Ural Federal University 620078, 19 Mira street, Ekaterinburg, Russia.

E-mail: yamalga@mail.ru 